\title{
Trace Metals Distribution in Sediment Fractions of Karimata Strait, Indonesia
}

\author{
Duaitd Kolibongso $^{1 *}$, Tri Prartono ${ }^{1}$ and Ali Arman ${ }^{2}$ \\ ${ }^{1}$ Department of Marine Science, Bogor Agricultural University, \\ Jl. Agatis, Kampus IPB Dramaga Bogor, West Java, 16680 Indonesia \\ ${ }^{2}$ Center for the Application of Isotopes and Radiation (PAIR), National Nuclear Energy Agency (BATAN) \\ Jl. Raya LebakBulus, South Jakarta, 12440 Indonesia \\ Email: duaitd91kolibongso@gmail.com
}

\begin{abstract}
The profile concentration of heavy metals, organic matter and the composition of the grain sizes is determined in two sediment cores from Karimata Strait. This study aimed to estimate the distribution of sediment grain sizes and distribution of heavy metals ( $\mathrm{Pb}, \mathrm{Cu}, \mathrm{Zn}, \mathrm{Ni}, \mathrm{As}$, and Fe) in three sediment fractions (>250 $\mu \mathrm{m}, 63-250 \mu \mathrm{m}$ and $<63 \mathrm{~m}$ ) of Karimata Strait. Sampling was conducted using box core. Graining size analysis was carried out through sieving, continue with digestion, and analyze the heavy metals using Inductively Coupled Plasma-Optical Emission Spectrometry (ICP-OES). Results of the study show that the sediment grain size distribution is strongly influenced by the water hydrodynamic condition (currents). It can be seen by the dominance of finding coarse grain size in the research areas. The highest concentration of the heavy metals was found in the finest grain size $(<63 \mathrm{~m})$ due to the larger surface area and higher adsorption capacity. Distribution of heavy metals $\mathrm{Cu}, \mathrm{Pb}, \mathrm{Zn}$ and $\mathrm{Ni}$ in the upper layer of sediments is higher than in the bottom layer. Furthermore, the As and Fe concentration in the surface were lower than in the bottom layer. Statistical analysis shows an association and a source of heavy metals mainly coming from the surrounding areas. It is supported by the enrichment factor values of finding heavy metals generally has been undergone enrichment.
\end{abstract}

Keyword: Grain sizes, Heavy metals, ICP-OES, Karimata strait, Sediment

\section{Introduction}

Karimata Strait is a part of the Sunda shelf. Geological characteristic of the strait is a long process of tectonically movements. The strait belongs to the neritic shallow water $(<85 \mathrm{~m})$ and has deposits and enriched small quartzes of volcanic ashes that consists of deposits coming from mainland, rivers, deltas kolluvial, marshes, and the kaolin clays coming from weathering and volcanoes muds that contain a lot of mineral deposits such as gold, copper, lead and zinc, bauxite, and kaolinite. Moreover, the strait water connects the South China Sea and Java Sea with different directions of current patterns movement in every season due to be affected by monsoon. The other interesting characteristic of the strait is being located in both big islands, Kalimantan and Sumatra. Hydrological complexities, human activities around the water and many rivers that flow into this strait contribute certainly to the environmental condition change (Alkausar, 2008; Susanto et al., 2013; Dewi, 2014). One of them is an increasing amount of materials that enter to the strait through raining and depositing atmospherics.

Geochemical studies in sediment can be used as a tool to delve environmental changes within a certain time (Horowitz, 1985; Benamar et al., 1999; Adamo et al., 2005). Marine sediment attribute is an output of land and sea interaction recording. Sea is affected by two sources such as recording land influences come from transported materials through rivers and runoffs and recording chemical and physical reactions in the sediments (Friedman and Sander, 1978; Rifardi, 2002; Segar, 2012).

The grain size is an important indicator that can illustrate spatial changes, deposition process, and environmental characteristics of the sediment; and identifies the sediment sources (Ujevic, 2000). It affects heavy metals concentration in sediment. Heavy metal is highly associated with grain sizes of fine sediment especially silt or clay fraction. In other side, heavy metals have significant ecological influences relating to the accumulating process in sediments and biotas (Yao et al., 2015). However, some recent researches show that coarse grain sizes especially sand fraction has high heavy metal concentration and even more concentration than finest particles (Whitney, 1975; Tessier et al., 1982; Krumgalz, 1989; Parizanganeh, 2008).

To understand environmental changes by related grain sizes and heavy metals approaches can
*) Corresponding author
(C) IImu Kelautan, UNDIP

ijms.undip.ac.id

DOI:10.14710/ik.ijms.22.4.174-184 
interpret environment condition and identify their sources with the result that can predict the Karimata strait evolution process in the future. This research aimed to analyze distributing and depositing sediments based on their grain sizes and contained heavy metals. This research is supposed canillustrate heavy metals property in the sediments and their sources which contributes to provide environmental change information of the strait.

\section{Materials and Method}

\section{Collection of sediment and sampling location}

The collected sediment coresamples were taken using a core box with dimension $50 \times 50 \times 50 \mathrm{~cm}$ at two stations in Karimata Strait. First location was on B3 that represented offshore area with high average current speed. The second location was on St 9 representing an area that close to the mainland (Kalimantan) and the Karimata's small chained islands (Figure 1.). Those core sampling were conducted by Baruna Jaya VIII research vehicle cruise on June 2015 and stored in refrigerator at $-4^{\circ} \mathrm{C}$ until further analysis in laboratory. They were analyzed in the Laboratory of Marine and Chemical Industry and Environment, Center for the Application Isotopes and Radiation (PAIR), National Nuclear Energy Agency (BATAN). Sampling coordinates location, water depth and sediment core length are shown in Table 1.

\section{Size fractionation}

Sediment samples were slices with interval 1 $\mathrm{cm}$ using plastic knives to avoid heavy metal contamination. Those interval samples were weighted and dried at $105^{\circ} \mathrm{C}$ for 24 hours (IAEA-TECDOC, 2003). Thus, each of the interval was homogenized by mortar and pestle.The homogenized sediment samples were sieved by using mesh size $70 \mu \mathrm{m}$ and mesh size $230 \mu \mathrm{m}$ for 15 minutes. These mesh sizes were aimed to fractionate grains from $>250 \mu \mathrm{m}, 63-$ $250 \mu \mathrm{m}$ and $<63 \mu \mathrm{mbased}$ Wentworth scale (Boggs, 2006). Sediment retained on each sieve was carefully remove and weighed. All fractions were then analyzed for their heavy metals concentration $(\mathrm{Pb}, \mathrm{Cu}$, $\mathrm{Zn}$, Ni and As). Organic matters were determined by the percentage of lost on ignition (Heiry et al., 2001; Robertson, 2011).

Tabel 1. Two Sampling Sediment Coring Property of Karimata Strait.

\begin{tabular}{ccccc}
\hline Station & Longitude & Latitude & $\begin{array}{c}\text { Depth } \\
(\mathrm{m})\end{array}$ & $\begin{array}{c}\text { Core } \\
(\mathrm{cm})\end{array}$ \\
\hline B3 & $108^{\circ} 32^{\prime} 49.5^{\prime \prime}$ & $1^{1054^{\prime} 64.8 ”}$ & 40 & 28 \\
9 & $109^{\circ} 3^{\prime} 48.8^{\prime \prime}$ & $1^{\circ} 4^{\prime} 08.3^{\prime \prime}$ & 27 & 5 \\
\hline
\end{tabular}

\section{Heavy metals analysis}

Digestion of sediment for heavy metals analysis was done by using a closed vessel microwave-assisted digestion method (Adiyiah et al., 2014). Each of interval and fractionation were weighted about $0.3 \mathrm{~g}$ and put into a vessel. Those samples were added with $9 \mathrm{ml} \mathrm{HNO}_{3}$ and $3 \mathrm{ml} \mathrm{HCl}$ (3:1) and $1 \mathrm{ml}$ of $\mathrm{H}_{2} \mathrm{O}_{2}$ was dropped in slowly. The vessels were then sealed carefully with their respective corks and heated using a microwave at $150^{\circ} \mathrm{C}$ with 700 Watts intensely for 30 minutes. Then those solvent samples were transferred into $50 \mathrm{~mL}$ volumetric flask and centrifuged at 3,000 rpm for 30 minutesto allow any suspended particles to settle. The solution was then decanted into a PPE plastic cup and diluted to $10 \mathrm{ml}$ with distilled water (EPA 3015A, 2007). Measurements of heavy metals were done using Inductively Coupled Plasma-Optical Emission Spectrometry (ICP-OES). The accuracy of the analytical procedure was repeatedly checked by analyzing samples of reference material SRM-158 (marine sediment) provided by the International Atomic Energy Agency (IAEA). Those samples and the standard sediment were applied with the same manner. The compliance of obtained results with the referred values is shown in Table 2. All results were reported on a dry weight basis. As a further quality assurance measure, method blanks were performed to check for the presence of contamination during the digestion and analytical procedures. The method blanks confirmed the absence of contamination for both procedures.

\section{Enrichment Factor (EF)}

Enrichment Factor (EF) was employed to assess the degree of contamination and to understand the distribution of heavy metals elements of anthropogenic origin from sites by individual elements in sediments that was first proposed by Simex and Helz (Zhang et al., 2007). EF method normalized the measured data concentration of heavy metals in sediment with a reference sample. Iron (Fe) was chosen as the normalizing element while determining EF values, since in wetlands it is mainly supplied from sediments and is one of the widely used reference element (Seshan et al., 2010; Sekabira et al., 2012). EF heavy metal was calculated by using the equation:

$$
\mathrm{EF}=\frac{\left(\frac{\mathrm{E}}{\mathrm{Fe}}\right) \text { sample }}{\left(\frac{\mathrm{E}}{\mathrm{Fe}}\right) \text { background }}
$$

where $E$ is the concentration of elements " $n$ ". The background value is that of average in earth crust (Taylor, 1964). Elements which are naturally derived have an EF value of nearly unity, while elements of 



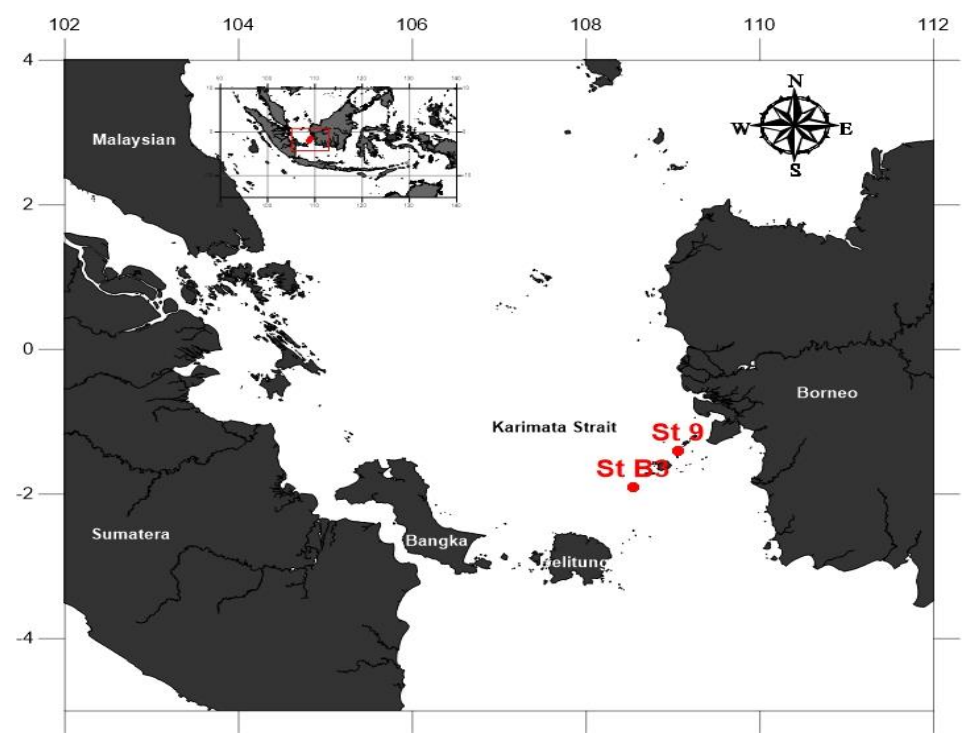

Figure 1. Research Map Location of Sampling at Karimata Strait

anthropogenic origin have EF value of several orders of magnitude. Six categories are recognized: $\leq 1.5$ no enrichment, 1.5-2 depletion to minimal enrichment, 2-5 moderate, 5-20 significant, 20-40 very high, and $>40$ extremely high enrichment.

\section{Results and Discussion}

\section{Grain sizes}

Classification of sediment types based on grain size indicated by the composition of two sediment cores do not differ greatly (Figure 2 and 3.). Generally, sediment at station B3 dominated coarser grain size $(>250 \mu \mathrm{m})$ with a percentage of the core $>60 \%$. Meanwhile, stations 9 are dominated 2 two grain size, the size of $63-250 \mu \mathrm{m}$ and $>250 \mu \mathrm{m}$ with a percentage of each in a core of about $40 \%$. Vertical distribution profile of grain size composition also differed between the two stations. At station B3 share coarse particles (>250 $\mu \mathrm{m})$ lower in the deeper layer and slowly increase in surface. Meanwhile, the composition of the grain size of stations 9 tend to be uniform between grain size $>250 \mu \mathrm{m}$ and $63-250 \mu \mathrm{m}$ along the core. Differences dominance sediment grain size on both stations is the influence of environmental conditions that flows as a transport medium particles at both locations. Alkausar (2008) found that the speed of currents in the Strait Karimata decline approaching coastal waters and increasing offshore. Grain size distribution profile of the two cores also indicate the fine grain size $(<63$ $\mu \mathrm{m})$ that goes to the Karimata Strait transported towards the sea (station B3) continues to increase.

Organic matter in marine sediments is usually derived from terrestrial environments, marine and anthropogenic sources. The total percentage of organic matter in the sediment station B3 was about $>20 \%$ and station 9 about $<20 \%$ (Figure 4.). Distribution of total organic material indicates organic matter content is generally found to be high in the surface layer and decreased with increasing depth. However, the station B3 found little variation in the organic matter content of the sediment profile. This condition is thought to be the result by turns between grain sizes during the process of sediment deposition.

\section{Vertical distribution of trace elements}

The concentration of heavy metals in the three sediment fraction $>250 \mu \mathrm{m}, 63-250 \mu \mathrm{m}$, and $<63 \mu \mathrm{m}$ displayed in Figure 5 and 6 . The results show the heavy metal concentrations in each different fraction vary greatly. This indicates a different effect on each sediment grain size in binding heavy metals. Concentrations of heavy metals $(\mathrm{Cu}, \mathrm{Pb}, \mathrm{Zn}, \mathrm{Ni}, \mathrm{As}$, and $\mathrm{Fe}$ ) are found high in the fine fraction (particlesize $<63 \mu \mathrm{m}$ ) where the value two times $(2 \mathrm{x})$ higher than the grain size $>250 \mu \mathrm{m}$ and 63-250 $\mu \mathrm{m}$. But unlike other metals $\mathrm{As}$ and $\mathrm{Fe}$ metal concentrationsin particular at the station B3 was found to increasethe grain size of $63-250 \mu \mathrm{m}$

Tabel 2. Comparison of the certifiedand obtained values (mg.kg-1 dry wt) for trace metal concentration in standard reference material SRM 158.

\begin{tabular}{cccc}
\hline Element & Standard & Obtained & $\begin{array}{c}\text { Recovery } \\
(\%)\end{array}$ \\
\hline $\mathrm{Pb}$ & $39.6 \pm 4.7$ & $41 \pm 3.4$ & 103.3 \\
$\mathrm{Cu}$ & $48.3 \pm 4.2$ & $46.3 \pm 7.5$ & 95.9 \\
$\mathrm{Zn}$ & $140.6 \pm 9.5$ & $134.9 \pm 10$ & 95.9 \\
$\mathrm{Ni}$ & $30.3 \pm 2.9$ & $28.3 \pm 2.2$ & 93.3 \\
$\mathrm{As}$ & $11.5 \pm 1.2$ & $11.1 \pm 1$ & 96.7 \\
$\mathrm{Fe}$ & $26300 \pm 1.4$ & $20100 \pm 2.6$ & 76.8 \\
\hline
\end{tabular}


The concentration of heavy metals in the fine grain size is generally associated with a surface area and organic matter content is high in adsorbing metals (Krumgalz et al., 1989; Adiyiah et al., 2014). High metal concentration in the coarse grain size is generally associated with the formation of agglomeration of coarse particles, the content of carbonates, and metal characteristics (Krumgalz, 1989; Singh 1999: Parizanganeh, 2008).

Heavy metals distribution profile in each grain size in both cores generally show the highest concentrations are found in the surface layer while heavy metals distribution profile As and Fe demonstrated low concentrations in the surface layer (especially the station B3) (Figure 5.). It is suspected because of the input from the surrounding area and the influence of fine sediment grain size in the surface layer is higher than in the inner layer. Described vertical profiles elevated concentrations in upper layer of sediment are typical for process of sediment loading by input from the surrounding area (Ujevic et al., 2000). Meanwhile, the high As and Fein the deeper layer relates to the size of coarse grains ishigh on the inner lining. As and Fe properties found inthe station B3 expected to be more inclined to associate and form a bond with a coarse grain size. This is supported by observations made at the station 9 which shows the opposite where As concentrations at this station higher in fines grain size. Concentration and vertical distributions of heavy metals in sediment may be controlled by numerous factors such as: the mineral composition of the sediment, carrier substances (for example: hydroxides, carbonate, sulfide), and effects of Eh and $\mathrm{pH}$. But, the efficiency of the various above factors in

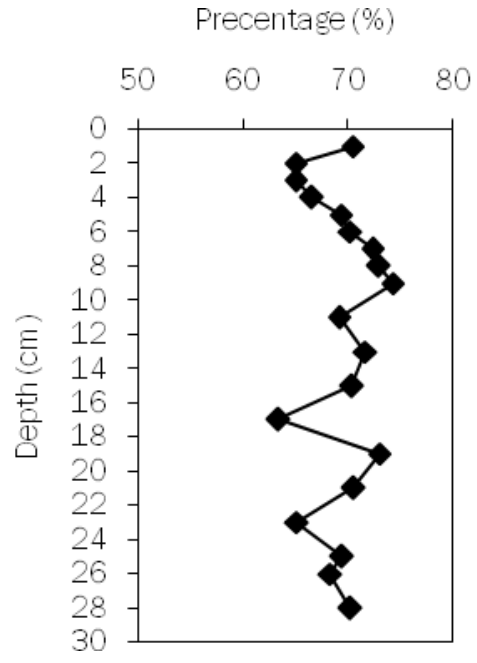

(a) $>250 \mu \mathrm{m}$

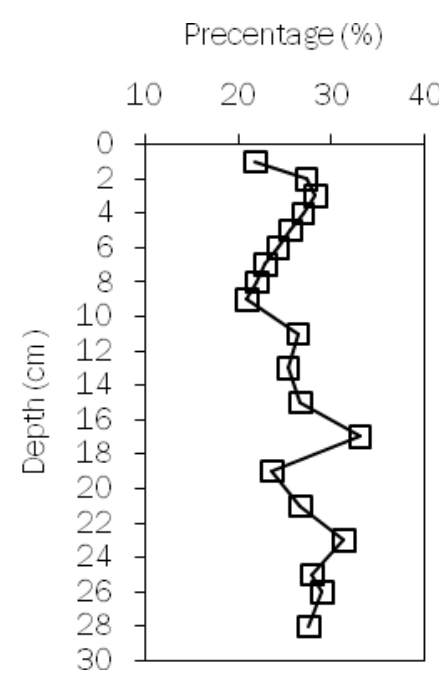

(b) $63-250 \mu \mathrm{m}$

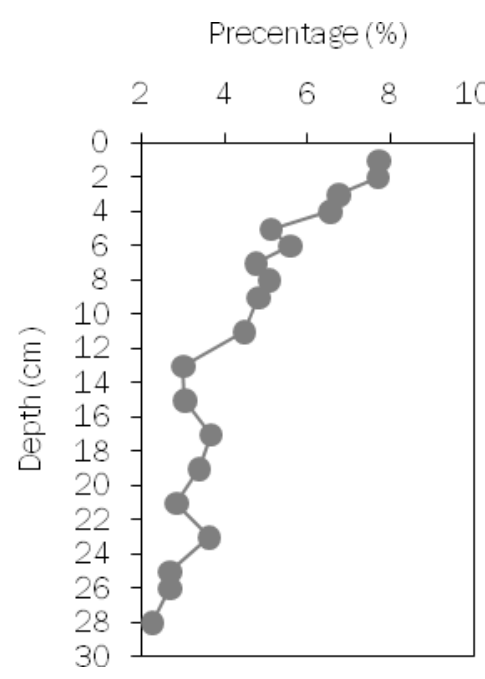

(c) $<63 \mu \mathrm{m}$

Figure 2. Grain size distribution at station B3

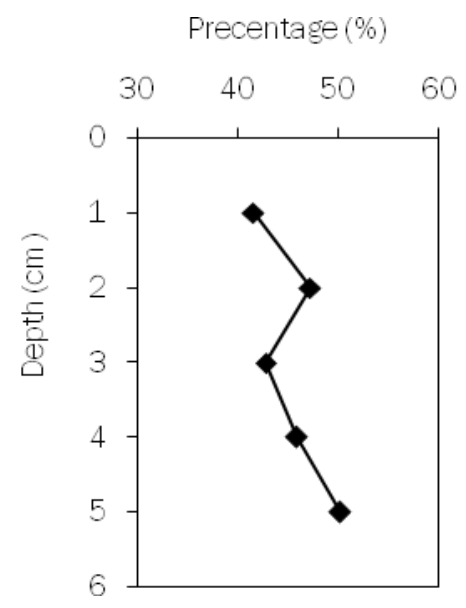

(a) $>250 \mu \mathrm{m}$

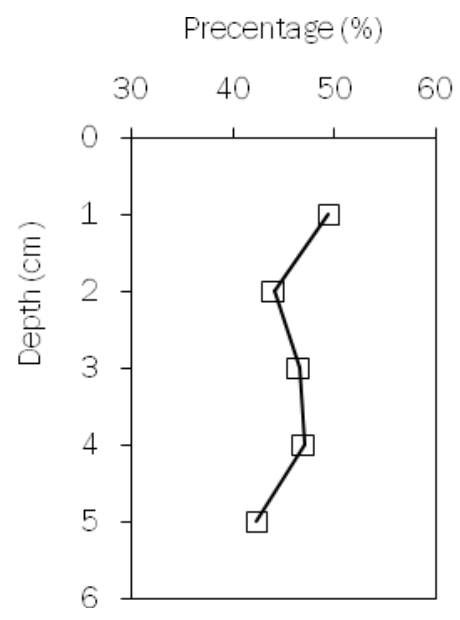

(b) $63-250 \mu \mathrm{m}$

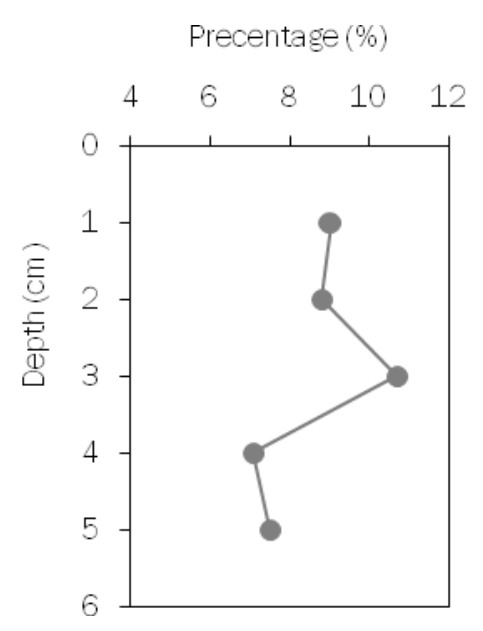

(c) $<63 \mu \mathrm{m}$

Figure 3. Grain size distribution at station 9 
influencing the binding and increased concentrations of heavy metals in sediments depend on the environmental conditions of sediment deposited, salinity, and water hydrodynamic conditions. Each grain size have different mobility in the marine environment, and the distribution of

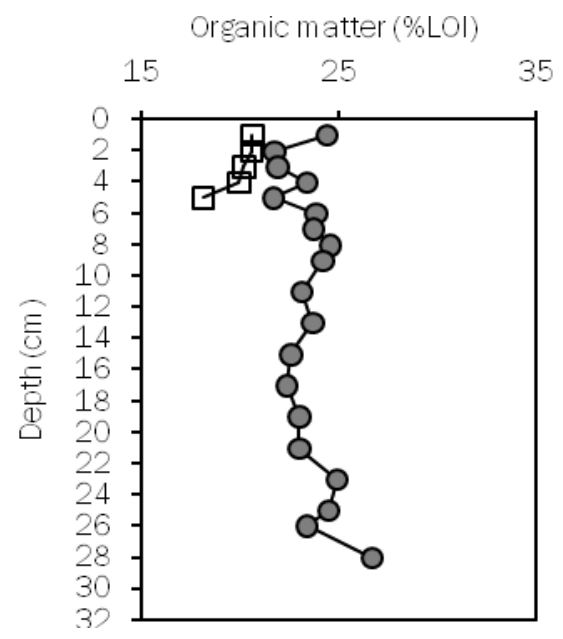

Figure 4. Organic matter distribution in core sediment

Note: Ð : Station 9, -○一 : Station B3

$\mathrm{Zn}\left(\mathrm{mg} . \mathrm{kg}^{-1}\right)$

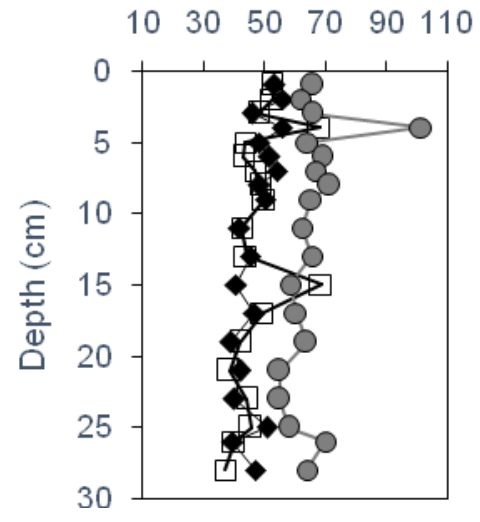

As (mg.kg-1

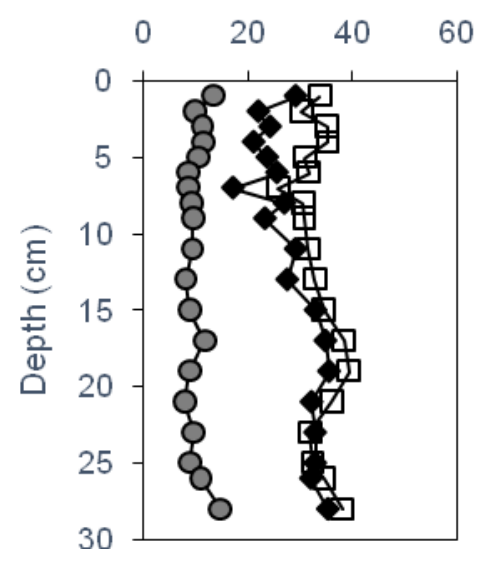

$\mathrm{Pb}\left(\mathrm{mg} \cdot \mathrm{kg}^{-1}\right)$

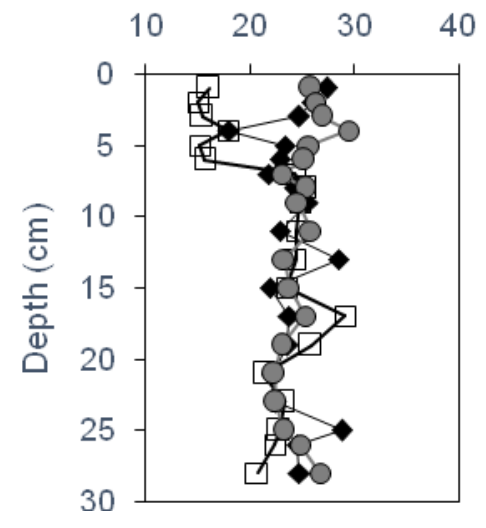

$\mathrm{Ni}\left(\mathrm{mg}^{\mathrm{kg}} \mathrm{kg}^{-1}\right)$

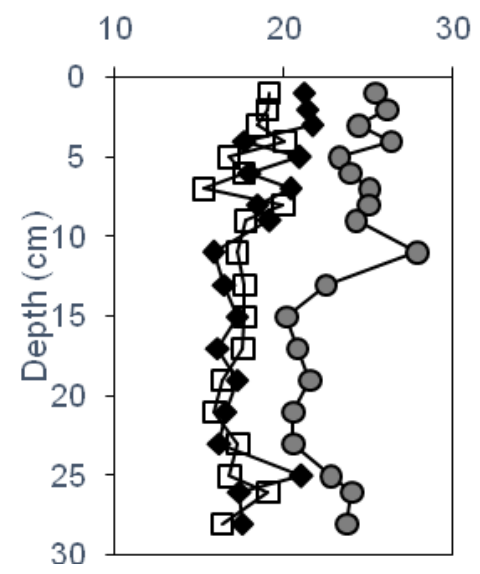

$\mathrm{Fe}\left(\mathrm{mg} \cdot \mathrm{kg}^{-1}\right)$

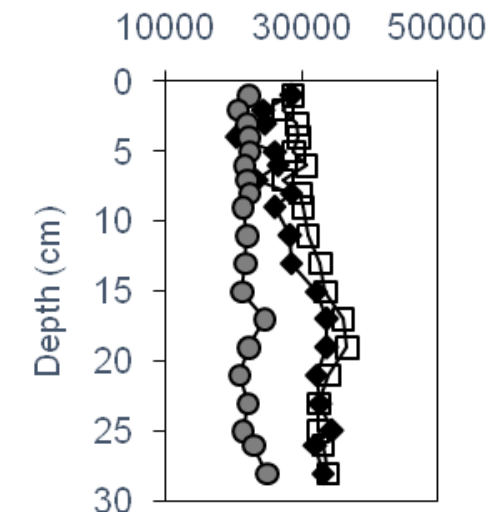

$\mathrm{Cu}\left(\mathrm{mg} \cdot \mathrm{kg}^{-1}\right)$

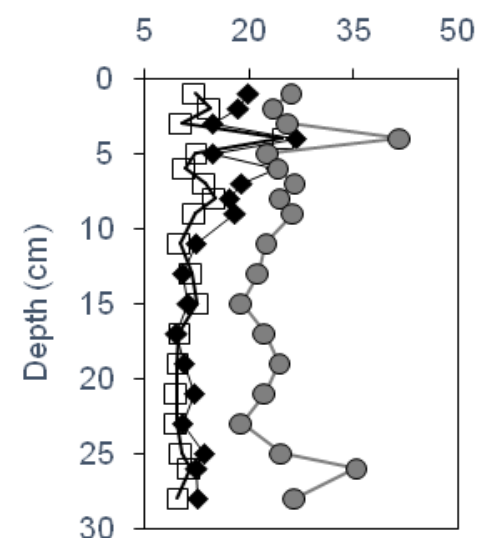

Figure 5. Heavy metal profile distribution at station B3

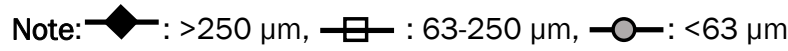


Zn (mg.kg-1)

3070110150190

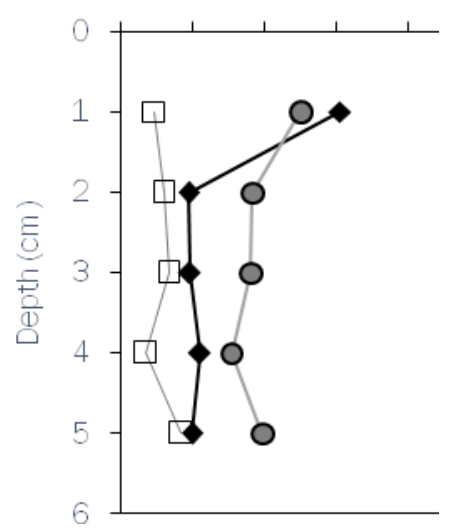

As ( $m g \cdot k g-1)$

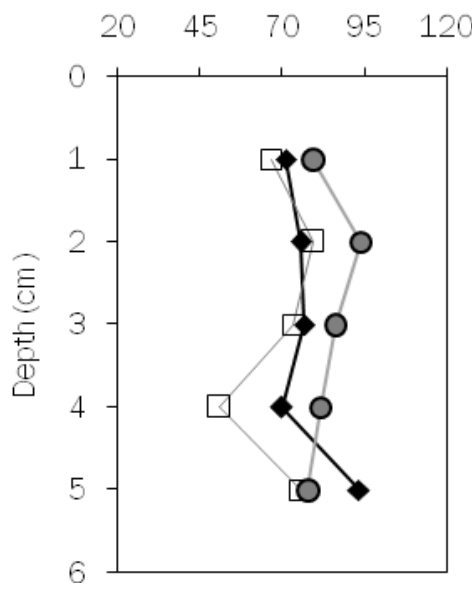

$\mathrm{Pb}$ (mg.kg-1)

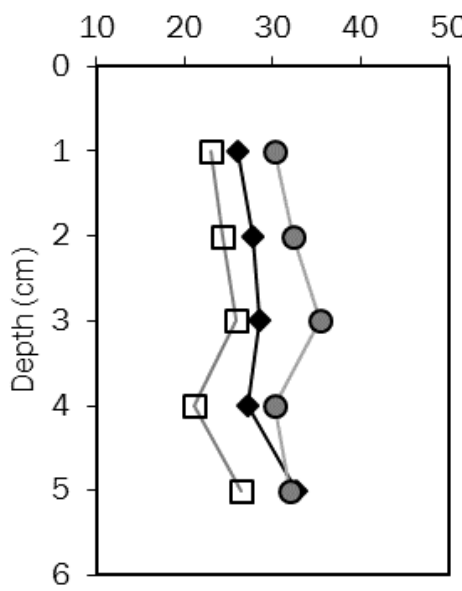

$\mathrm{Fe}$ (mg.kg-1)

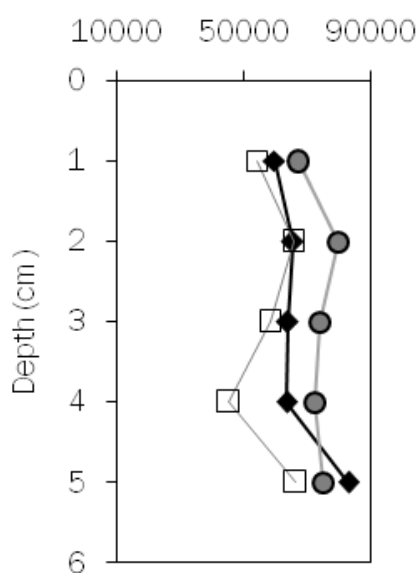

Ni (mg.kg-1)

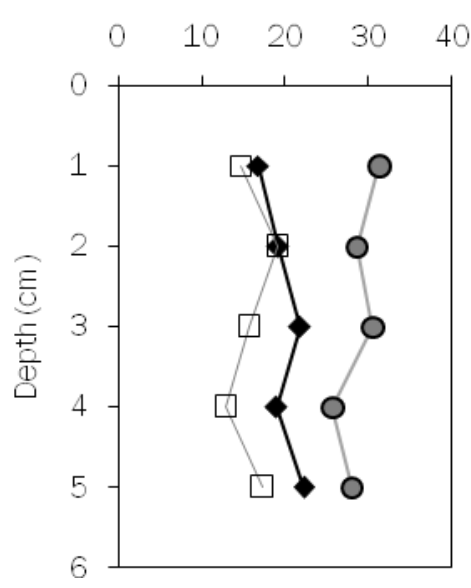

$\mathrm{Cu}(\mathrm{mg} \cdot \mathrm{kg}-1)$

2060100140180

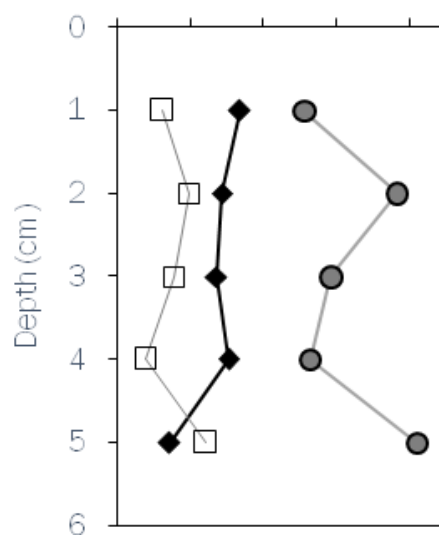

Figure 6.Trace metal profile distribution at station 9

Note:

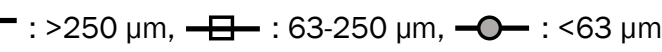

heavy metals in various grain sizes will also vary for different metals so that it can serve as a "fingerprint" the source of heavy metals in the water.

\section{Estimation of anthropogenic metal enrichment}

Comparison of metal concentrations in sediments with the reference value is generally used to estimate metal enrichment. Based on result, the highest EF value for heavy metals commonly found in the particle size of $<63 \mathrm{~mm}$ in the second compare other particles. This indicates that a higher percentage of fine grain size in the sediment causes sediments more susceptible to heavy metal contamination. Sequence enrichment of heavy metals in their respective grain sizes ranging from as low $\mathrm{As}>\mathrm{Pb}>\mathrm{Zn}>\mathrm{Cu}>\mathrm{Ni}$ at the station B3 while, sediments at station 9 shows the sequence from the lowest $\mathrm{As}>\mathrm{Pb}>\mathrm{Cu}>\mathrm{Zn}>\mathrm{Ni}$.
EF value distribution profile for each grain size showed on thebothcores, heavy metal enrichment.As significant experience very high (20-40), Pb were enriched medium (2-5), $\mathrm{Cu}$ and $\mathrm{Zn}$ enrichment minimal (1.5-2) and $\mathrm{Ni}$ did not experience enrichment $(<1.5)$ indicates where sediment conditions on both cores tend to have undergone any enrichment. According Sutherland (2000), states that the higher the EF, the contribution of anthropogenic sources is also increasing. Meanwhile, EF values in the range of 0.5 to 1.5 indicates that all metals tend to come from the material crust (the crust) or the result of natural weathering (Zhang et al., 2007).

\section{Anthropogenic vs. natural sediment sources}

The sources of trace elements were investigated by using Principal Component Analysis 
(PCA). PCA is a method which has been used in geochemical research in recent years due to its ability to reduce data in large datasets into a smaller number of Principal Components (PCs) that explain from the variance data. PCA can be used to group the elements based on their correlation to each other (Bingol et al, 2013). In this study, PCA was applied to the entire data set of trace elements. The PCA results are shown in Table 3 and 4 . Results of statistical analysis using PCA on all metal concentration data for each grain size in two sediment cores used to infer the source of the metalin the second core and which explained $72 \%$ of the total variance in the particle size of $>250 \mu \mathrm{m}, 85 \%$ of the total variance in particle size of $63-250 \mu \mathrm{m}$ and $80 \%$ of the total variance of particles $<63 \mu \mathrm{m}$ in stations B3 and the only one principal component with eigenvalue more than one, which explained $83 \%$ of the total variance in particle $>250 \mu \mathrm{m}, 89 \%$ of the total variance in the 63 $250 \mu \mathrm{m}$ particles and $47.4 \%$ of the total variance in particle $<63 \mu \mathrm{m}$ at the station 9 .

F1 explained $46.8 \%$ of the total variance in grain size $>250 \mu \mathrm{m}$ in the station B3, therein including a group of $\mathrm{Cu}, \mathrm{Zn}$ and $\mathrm{Ni}$. This indicates that all three of these metals form an association in grain size $>250 \mu \mathrm{m}$ and come from the same source, ie from the sea itself. This is supported by all three concentrations found to be low in the grain size and the value of EF who showed no enrichment. Fe is also included in this group. However, differences in loading components $\mathrm{Fe}$ showed a different distribution with other metals (low concentrations in the surface layer). F2 explained $25.4 \%$ of the total
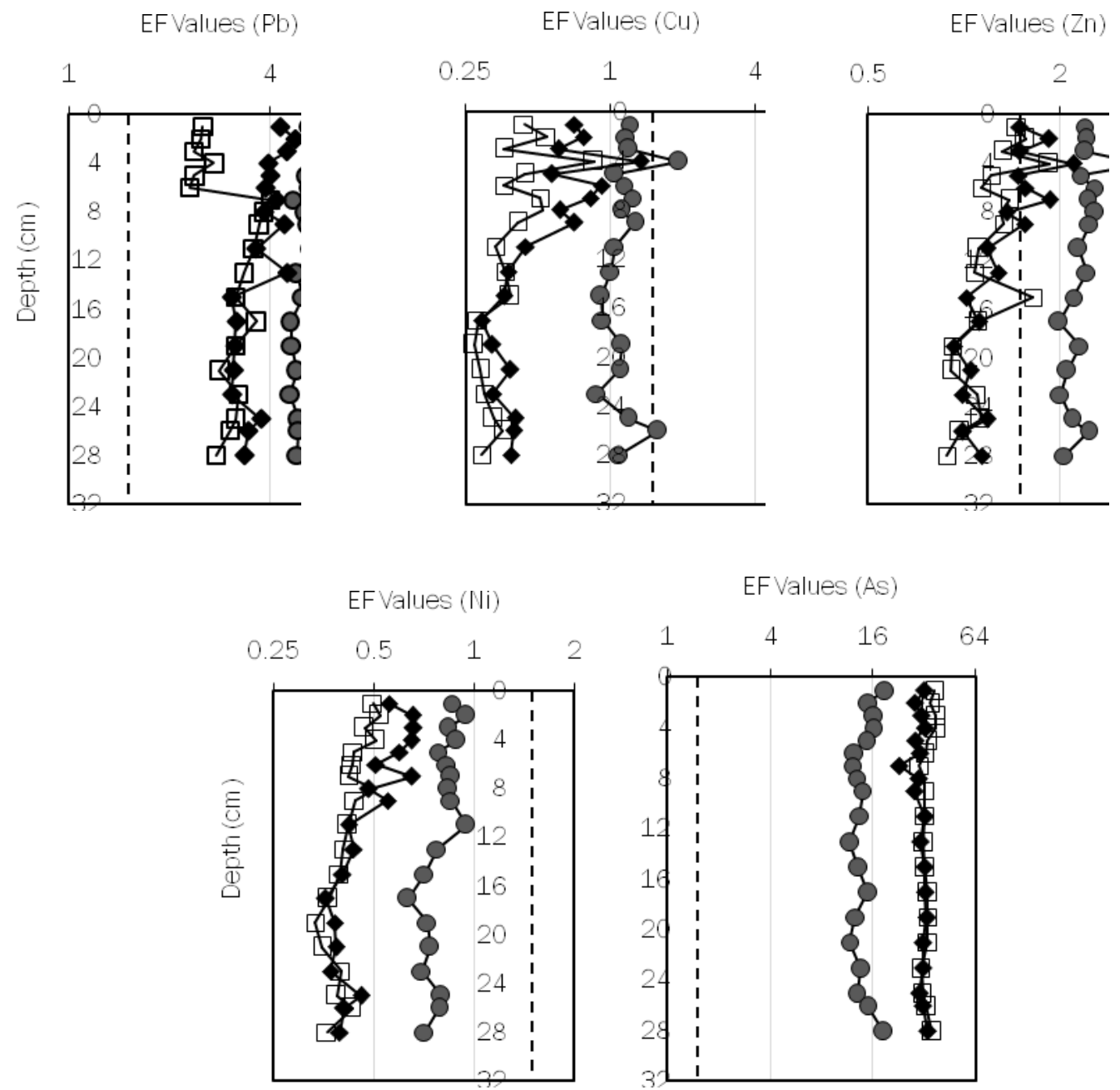

Figure 7.Distribution of Enrichment factor value of trace metal in core sediment station B3 (Zhang et al., 2007; dot line as a limit assess of enrichment factor $E F=1.5$ ) Note:

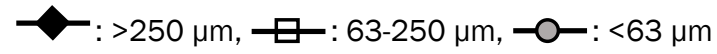

variance in grain size $>250 \mu \mathrm{m}$ As metal therein. The grain size $63-250 \mu \mathrm{m}$ therein As and Fe group metals. This condition indicates that these two metals originated from the same source. Fe is one of the main elements and its nature as a hydroxide will undergo a process of reduction of $\mathrm{Fe}^{3+}$ to $\mathrm{Fe}^{2+}$ which it would then affect the metal adsorption of As (Sanusi, 2006). And on the grain size $<63 \mu \mathrm{m}$ explain 
$55 \%$ of the total variance, which certainly includes $\mathrm{Pb}$, $\mathrm{Cu}, \mathrm{Zn}, \mathrm{Ni}$ and As. This condition indicates that all of these metals form associations with particle size of $<63 \mu \mathrm{m}$ and come from sources of anthropogenic activities on land that enter waters through run-off and input from rivers. At station 9, F1 explain $83 \%$ of the total variance in grain size $>250 \mu \mathrm{m}$ including a group of $\mathrm{Pb}, \mathrm{Ni}$, As and $\mathrm{Fe}$. This indicates the characteristics of $\mathrm{Pb}, \mathrm{Ni}$ and $\mathrm{As}$ to form associations and binds with Fe-oxides. $\mathrm{Cu}$ is also included in this group but the difference in loading showed differences in the distribution of sediments (Figure 5). This condition is suspected due to changes in redox conditions that usually occur in this bond which led to the release of $\mathrm{Cu}$. This can be seen from the EF value of $\mathrm{Cu}(\mathrm{EF}<1.5)$ in these particles is relatively experienced compared to the enrichment of $\mathrm{Pb}$ and As.

F1 explain $89 \%$ of the total variance in grain size $63-250 \mu \mathrm{m}$, and has a positive loading (>0.8) for $\mathrm{Pb}, \mathrm{Cu}, \mathrm{Zn}, \mathrm{Ni}, \mathrm{As}$, and $\mathrm{Fe}$. This illustrates that the association of these metals tend to bind to the Feoxide and carbonate fraction high in this grain size. That is to say the higher the concentration of $\mathrm{Fe}$ in 63-250 $\mu \mathrm{m}$ particle it will be followed by the higher concentration of heavy metals. Sutherland et al. (2012) found heavy metals commonly found associated and attached to the fraction of $\mathrm{Fe} / \mathrm{Mn}$ oxides and carbonates in particular on the grain size class 63-250 $\mu \mathrm{m}$. Generally the metals bind to the fraction of carbonate and Fe-Mn oxide is a metal that the highest mobility (most available form) because it is easiest to exchange (most exchangeable) and weakly adsorbed on a matrix of sediment so that the most easily separated and dissolved in the water column and therefore it is the fraction of the most available and potentially absorbed and can cause toxicity in aquatic organisms (Sundaray et al., 2011). The main source of metals in these strong grain sizes thought to have come from the mainland around. And on the grain size $<63 \mu \mathrm{m}$ therein $\mathrm{Cu}$, Fe and As which explain the source of these metals come from activities on land around the station as well as from
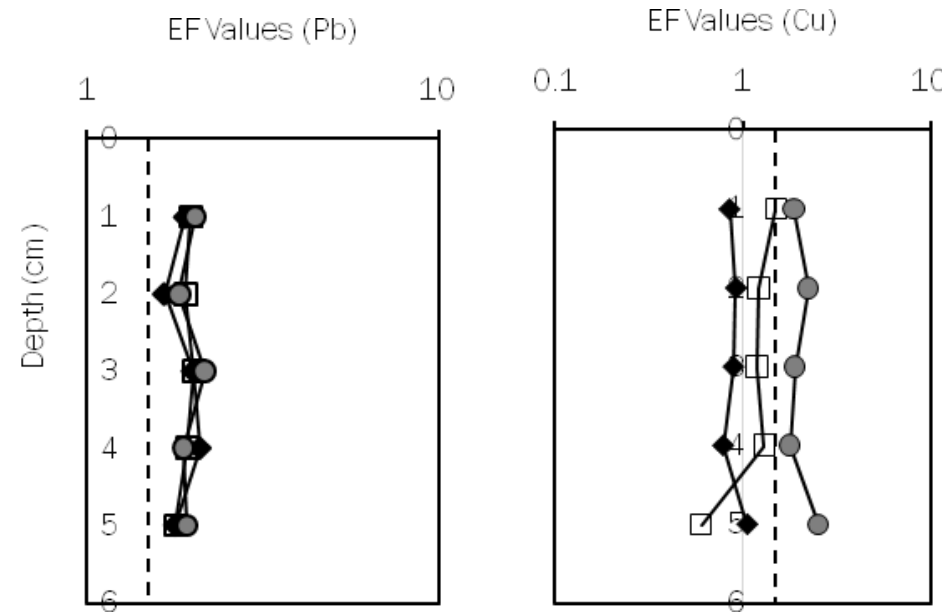

$$
\text { EF values (Zn) }
$$

0.1

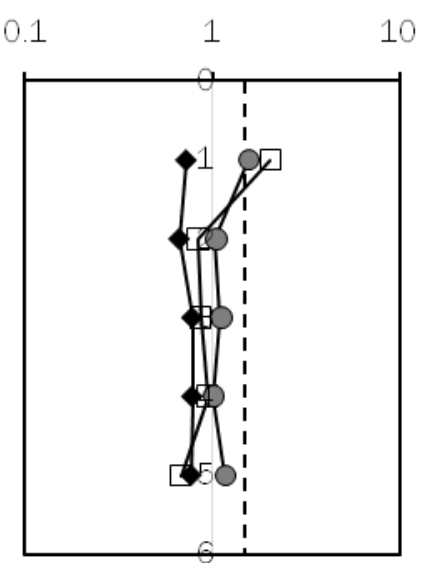

EF Values (Ni)
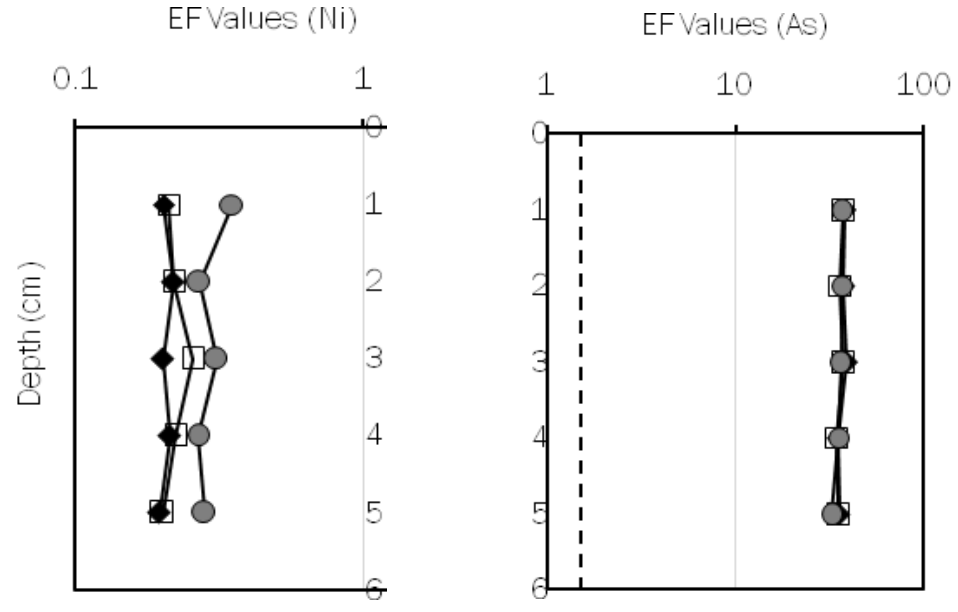

Figure 8. Distribution of enrichment factor value of trace metal in core sediment station 9. (Zhang et al., 2007; dot line as a limit assess of enrichment factor $E F=1.5$ ) Note: : $>250 \mu \mathrm{m}, \square:$ : $63-250 \mu \mathrm{m},-0-:<63 \mu \mathrm{m}$ 
Table 3. PCA result of trace metal concentration in grain size at station B3

\begin{tabular}{ccccccc}
\hline \multirow{2}{*}{ St B3 } & \multicolumn{2}{c}{$>250 \mu \mathrm{m}$} & \multicolumn{2}{c}{$63-250 \mu \mathrm{m}$} & \multicolumn{2}{c}{$<63 \mu \mathrm{m}$} \\
\cline { 2 - 7 } & $\mathrm{F} 1$ & $\mathrm{~F} 2$ & -0.886 & -0.181 & 0.833 & -0.235 \\
$\mathrm{Cu}$ & 0.817 & 0.356 & 0.166 & 0.935 & 0.910 & -0.004 \\
$\mathrm{~Pb}$ & -0.566 & 0.284 & -0.879 & 0.228 & 0.835 & -0.353 \\
$\mathrm{Zn}$ & 0.673 & 0.528 & -0.654 & 0.621 & 0.675 & -0.432 \\
$\mathrm{Ni}$ & 0.679 & 0.463 & 0.924 & 0.090 & 0.678 & 0.650 \\
$\mathrm{As}$ & -0.487 & 0.726 & 0.921 & 0.224 & 0.413 & 0.840 \\
Fe & -0.816 & 0.547 & 3.718 & 1.403 & 3.302 & 1.496 \\
Eigen value & 2.808 & 1.529 & 61.978 & 23.392 & 55.136 & 24.947 \\
\% Value & 46.814 & 25.491 & 61.978 & 85.371 & 55.136 & 80.083 \\
\% Cumulative & 46.814 & 72.305 & & & & $\mathrm{~F}$ \\
\hline
\end{tabular}

Table 4. PCA result from trace metal concentration in grain size at station 9

\begin{tabular}{cccc}
\hline \multirow{2}{*}{ St 9} & $>250 \mu \mathrm{m}$ & $63-250 \mu \mathrm{m}$ & $<63 \mu \mathrm{m}$ \\
\cline { 2 - 4 } & $\mathrm{F} 1$ & $\mathrm{~F} 1$ & $\mathrm{~F} 1$ \\
$\mathrm{Cu}$ & -0.988 & 0.973 & 0.142 \\
$\mathrm{~Pb}$ & 0.991 & 0.906 & 0.664 \\
$\mathrm{Zn}$ & -0.636 & 0.935 & 0.487 \\
$\mathrm{Ni}$ & 0.894 & 0.906 & 0.884 \\
$\mathrm{As}$ & 0.952 & 0.955 & 0.377 \\
$\mathrm{Fe}$ & 0.953 & 0.987 & 0.106 \\
Eigen value & 4.979 & 5.353 & 2.848 \\
\% Varian & 82.993 & 89.232 & 27.272 \\
\% Cumulative & 82.992 & 89.232 & 47.468 \\
\hline
\end{tabular}

distant areas or derived from anthropogenic inputs. Potential sources of heavy metals are mostly from mainland such as port and industrial activities (Rochyatun and Razak, 2007; Arifin and Fadhlina, 2009). Moreover, the existence of various industries, mining, plantation/agricultural areas near the mainland is estimated to dump wastes through rivers or drainage passing through the estuary towards the Strait Karimata.

\section{Conclusion}

Karimata Strait is shallow water with the composition of the grain size is not uniformly distributed. The highest concentrations of heavy metals found in the highest fine grain size.Heavy metals generally showed a minimal enrichment to very high. Results of statistical analysis using all data (concentrations of heavy metals in each grain size) indicates the association of heavy metals were found to differ in which it describes the source of the metals are also different.

\section{Acknowledgements}

The authors would like to extend their gratitude and grateful thanks to Center for Applications of Isotopes and Radiation (PAIR)-
National Nuclear Energy Agency (BATAN) especially the staff of Laboratory for supporting this work. We also wish to thank to Institute for Marine Research and Observation (BPOL) is Mr. Agung Yunanto and Baruna Jaya VIII research vessel crew for financially and supporting this work.

\section{References}

Adamo, P., Arienzo, M., Imperato, M., Naimo, D., Nardi, G. \& Stanzione, D. 2005. Distribution and partition of heavy metals in surface and subsurface sediments of Naples city port. Chemosphere. 61: 800-809. doi: 10.1016/j.che mosphere.2005.04.001

Adiyiah, J., Acheampong, M.A., Ebenezer, D., Anza, O. \& Kelderman, P. 2014. Grain-size Analysis and Heavy Metals distribution in sediment fraction of Lake Markermeer in the Netherland. J. Environ. Sci. Toxic. Res. 2 (8):160-167.

Alkausar, H. 2008. Model hidrodinamika pasang surut di Perairan Selat Karimata. Thesis. Bandung Institute of Technology. Bandung.

Arifin, Z. \& Fadhlina, D. 2009. Fraksinasi logam berat $\mathrm{Pb}, \mathrm{Cd}, \mathrm{Cu}$, dan $\mathrm{Zn}$ dalam sedimen dan 
bioavailibitasnya bagi biota di perairan Teluk Jakarta. IImu Kelautan. 14(1):27-32. doi: 10.14710/ik.ijms.1412732

Benamar, M.A., Toumert, I., Tobbeche, S., Tchantchane, A. \& Chalabi, A. 1999. Assessment of state of pollution by heavy metals in the surficial sediments of Algiers Bay. Appl. Radiation Isotopes. 50: 975-980. doi : 10.101 6/S0969-8043(98)00111-0

Bingol, D., Ay, U., Bozbas, K.S. \& Uzguren, N. 2013. Chemometric evaluation of the heavy metals distribution in waters from the Dilovasi region in Kocaeli, Turkey. Mar. Poll. Bull. 68: 134-139. doi : 10.1016/j.marpolbul.2012.12.006

Boggs, S.Jr. 2006. Principle of Sedimentology and Stratigraphy. Fourth Edition. Pearson Prentice Hall Publ.

Dewi, K.T. 2014. Ostracoda from subsurface sediments of Karimata strait as a indicator enviromental changes. Bull. Mar. Geology. 29(1): 1-10.

EPA 3015A. 2007. Microwave Assisted Acid Digestion of Aqueous Samples and Extracts. Washington DC (US): Environmental Agency Protection Press.

Friedman, G.M. \& Sanders, J.E. 1978. Principle of Sedimentology. John Wiley \& Sons Press. 792 pp.

Heiry, O., Lotter, A.F. \& Lemcke, G. 2001. Loss on ignition as a method for estimating organic and carbonate content in sediments: reproducibility and comparability of result. J. Paleolimnol. 25: 101-110. doi: 10.1023/A:1008119611481

Horowitz, J.A. 1985. A primer on trace metalsediment chemistry. United States Geological Survey Water. United States. 67 pp.

International Atomic Energy Agency-1360. 2003. Collection and preparation of bottom sediment samples for analysis radionuclides and trace elements. Nutritional Health-Related Environmental Studies Section IAEA. Vienna, Austria.

Krumgalz, B.S. 1989. Unusual Grain Size Effect on Trace Metals and Organic Matter in Contaminated Sediments. Mar. Pollut. Bull. 20 (12): 608-611. doi : 10.1016/0025-326X(89) 90397-4

Parizanganeh, A. 2008. Grain Size Effect in Trace Metals in Contaminated Sediments along the
Iranian Coast of the Caspian Sea. Proc. Taal: The $12^{\text {th }}$ World Lake Conference. P: 329-236.

Rifardi. 2002. Ecological analysis of living benthic Foraminifera surface sediment from the south Yatsushiro Kai (sea), Southwest Kyushu, Japan. J. Coast. Develop. 5 (3):117-129.

Robertson, S. 2011. Direct Estimation of Organic Matter by Loss on Ignition: Methods. SFU Soil Science Lab. Simon Fraser University.

Rochyatun, E. \& Rozak, A. 2007. Pemantauan kadar logam berat dalam Sedimen di PerairanTeluk Jakarta. Makara Sains. 11(1): 28-36. doi: 10.7454/mss.v11i1.228

Sanusi, H.S. 2006. Kimia Laut-Proses Fisik Kimia dan Interaksinya dengan Lingkungan. Bogor: Marine Science and Technology Department. Faculty of Fisheries and Marine Science. Bogor Institute of Agriculture. Bogor.

Segar, E.S. 2012. An Introduction to Ocean Sciencethird edition. Liverpool University Press. 510 pp

Sekabira, K., Kakudidi, E., Mutumba, G., Oryem-Origa, H. \& Basamba, T.A., 2012. Grain Size and Source Apportionment of Heavy Metals in Urban Stream Sediments. INTECH Open Access Publisher.

Seshan, B.R.R., Natesan, U. \& Deepth, K. 2010. Geochemical and statistical approach for evaluation of heavy metal pollution in core sediments in southeast coast of India. Int. J. Environ. Sci. Tech. 7(2): 291-306. doi: 10.1007 /BF03326139.

Singh, A.K., Hasnain, S.I. \& Banerjee, D.K. 1999. Grain size and geochemical partitioning of heavy metals in sediments of the Damodar River-a tributary of the lower Ganga, India. Environ. Geology. 39(1): 90-98. doi: 10.1007/s002540 050439

Sundaray, S.K., Nayak, B.B., Lina, S. \& Bhatta, D. 2011. Geochemical speciation and risk assessment of heavy metals in the river estuarine sediments, a case study: Mahanadi basin, India. J. Hazard. Mater. 186: 1837-1846. doi: 10.1016/j.jhazmat.2010.12.081

Susanto, R.D., Zexun, W., Rameyo, A.T., Bin, F., Shujian, L.I. \& Guohong, F. 2013. Observation of Karimata strait throughflow from December 2007 to November 2008. Acta Oceanol. Sin. 32 (5): 1-6. doi: 10.1007/s13131-013-0307-3 
Sutherland, R.A. 2000. Bed sediment-associated trace metals in an urban stream, Oahu, Hawaii. Environment. Geol. 39 (6): 611-627. doi: $10.1007 / \mathrm{s} 002540050473$

Sutherland, R.A., Tack, F.M.G. \& Ziegler, A.D. 2012. Road-deposited Sediments in a urban environment: A first look at sequentially extracted elements loads in grain size fractions. J. Hazard. Mater. 225-226: 54-62. doi: 10.1016/j.jhazmat.2012.04.066.

Taylor, S.R. 1964. Abundance of chemical elements in the continental crust: a new table. Geochimicaet Cosmochimica Acta. 28: 12731285.

Tessier, A., Campbell, P.G.C. \& Bison, M. 1982. Particulate trace metal speciation in stream sediments and relationship with grain size: Implication for geochemical exploration. J. Geochem. Explor. 6: 77-104. doi: 10.1016/0375-6742(82)9002 2-X
Ujevic, I., Odzak, N. \& Baric, A. 2000. Trace Metal Accumulation in Different grain Size Fractions of the Sediments from a Semi-Enclosed Bay Heavily Contaminated by Urban and Industrial Wastewaters. Water Res. J. 34 (11): 3055-3061. doi : 10.1016/S0043-1354(99)00 376-0

Whitney, P.R. 1975. Relationship of manganese-iron oxides and associated heavy metals to grain size in strein sediments. J. Geochem. Explor. 4:251263.

Yao, Z., Liu, Y., Shi, X. \& Suk, B.C. 2012. Paleoenvironmental Changes in The East/Japan Sea During The Last 48 ka : Indications From High Resolution X-Ray Fluorescence Core Scanning. Quater Sci. 27(9):932-940. doi: 10.1002/jqs.2583

Zhang, L., Xin, Ye., Feng, H., Jing, Y., Ouyang, T., Yu, X., Liang, R., Gao, C. \& Chen, W. 2007. Heavy metal contamination in western Xiamen Bay sediments and its vicinity, China. Mar. Poll. Bull. 54:974982. doi: 10.1016/j.marpolbul.2007.02.010 